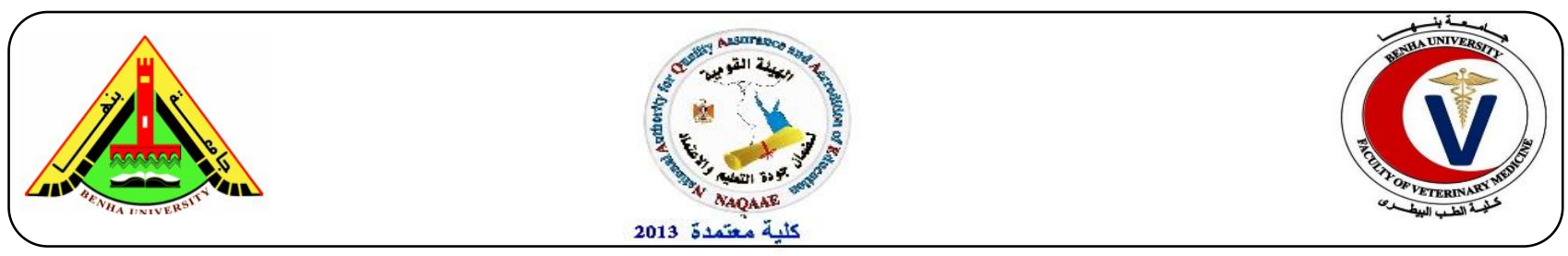

\title{
Isolation and Molecular Identification of Avian Paramyxovirus-1 from Broiler Outbreak in Qaliobia Governorate, Egypt
}

\author{
Nermin M. Monir ${ }^{1}$, Gabr F. El-Bagoury ${ }^{2}$, Lamia M. Omar ${ }^{1}$, Saad S. A. Sharawi ${ }^{2,}$ Arafa A $^{3}$. \\ ${ }^{1}$ Central Laboratory for Evaluation of Veterinary Biologics, Cairo. \\ ${ }^{2}$ Department of Virology, Faculty of Veterinary Medicine, Benha University. \\ ${ }^{3}$ National Laboratory for Veterinary Quality Control on Poultry Production.
}

\section{A B S T R A C T}

The worrying Newcastle disease is endemic in Egypt with outbreaks occurring from one time to another causing dramatic economic losses in poultry flocks. The current study was a trial to isolate and identify NDV from poultry flocks in Egypt during 2015 and 2016. The NDV was isolated in the allantois cavity of specific pathogen free embryonated chicken eggs (SPF-ECE). The hemagglutination positive isolates were identified as NDV by Hemagglutination inhibition test (HI) and genetically by Reverse Transcriptase-Polymerase Chain Reaction (RT-PCR). Estimating the virulence of the isolated NDV by partial $F$ gene sequencing and intra-cerebral pathogenicity index (ICPI)calculation that was found to be (1.51). Titer of the propagated NDV isolate was $10 \log _{2} \mathrm{HA}$ and by ECE inoculation was $10^{9.7} \mathrm{EID}_{50} / \mathrm{ml}$. Our results indicated that the new isolate is virulent and genetically related to genotype VIId NDV which emphasize the importance of NDV surveillance for improving strategies for disease control.

Keywords: NDV, poultry, ICPI, RT-PCR

(http://www.bvmj.bu.edu.eg)

(BVMJ-34(2): 265-277, 2018)

\section{INTRODUCTION}

Newcastle disease caused by Avian paramyxovirus serotype 1(APMV-1),is considered one of the most devastating poultry infections because of its worldwide distribution and economical threat (Leslie,
2000).By serological tests and phylogenetic analysis, the paramyxoviruses isolated from avian species, is classified to ten subtypes APMV-1 to APMV-10, from which APMV-1 (NDV) is the best studied because virulent 
NDV strains cause severe disease in chickens (Miller et al., 2010).NDV strains are classified to (lentogenic, mesogenic and velogenic) pathotypes based on severity of disease they cause, which is determined by in vivo pathogenicity test parameters as the intracerebral pathogenicity index in 1 day-old SPF chick(Alexander ,1988). The virus genome encodes six proteins which are: nucleocapsid (NP), phosphoprotein $(\mathrm{P})$, matrix (M), fusion $(\mathrm{F})$, hemagglutinin-neuraminidase $(\mathrm{HN})$, and the RNA-dependent RNA polymerase (L) (Kattenbelt et al., 2006).The glycoproteins HN and $\mathrm{F}$ allow binding and fusion of the virus to the host cells to initiate NDV infection, two additional proteins: $\mathrm{V}$ and $\mathrm{W}$ produced from RNA editing of the $\mathrm{P}$ protein(Miller et al., 2007). The primary determinant for NDV virulence is known to be related to ability of precursor $F(F 0)$ to cleave active $F 1$ and $F 2$ polypeptides by cellular proteases (Lomnicizi et al., 1998). At the F0 cleavage site, there is multi basic amino acid sequence (i. e. ${ }^{112} \mathrm{RRQKRF}^{117}$ ) in the viruses virulent for chicken (Aldous et al., 2003). According to genome length and F-protein gene ( $\mathrm{F}$ gene) sequence, NDV strains have been classified to two major classes: class I strains, which have been mainly isolated from wild birds and generally avirulent, and class II strains which have been recovered from wild and domestic birds and include virulent and avirulent strains. Both classes of viruses I and II are further divided to 9 and 15 genotypes, respectively (Diel et al., 2012). In Egypt ND is considered a continuous renewable problem because of several repeated outbreaks in vaccinated and non-vaccinated birds in both backyard and commercial farms. The epidemiology of the virulent NDV isolates from these outbreaks is not known. Continuous effort usually is made to control or eradicate New castle in poultry. In particular, further isolation and identification of ND virus will help in development of control measures of the disease.

Therefore, the present study was conducted to isolate, molecular characterize newly isolated NDV from recent outbreak in Egypt.

\section{Materials and methods}

\subsection{Sample collection and processing acc. to (Swayne, 2013):}

Clinical specimens including (trachea, spleen and liver) were collected from freshly dead birds of 31 commercial broiler and layers farms (chicken and turkey) from four Egyptian provinces during 2015 and 2016 as shown in Table (1). They were suspected to be NDV infected since they were suffering from depression, high percentage of mortality, sever green diarrhea, drop in egg production in layers. The specimens were grinded in PBS, $\mathrm{pH} \mathrm{7.4,} \mathrm{containing} \mathrm{antibiotics.} \mathrm{After} \mathrm{three}$ cycles of freezing and thawing, the samples were clarified by centrifugation at $3000 \mathrm{rpm}$ for $10 \mathrm{~min}$. at $4^{0} \mathrm{C}$, then the supernatants were collected and stored at $-70^{\circ} \mathrm{C}$ until used.

\subsection{Virus isolation:}

The specimen's supernatants were inoculated into 9-11 day old embryonated chicken specific-pathogen-free (SPF) eggs via the allantois route using $0.2 \mathrm{ml} / \mathrm{egg}$, then incubated for 5 days at $37{ }^{\circ} \mathrm{C}$, eggs showing embryonic death within $24 \mathrm{hrs}$. of inoculation were discarded and the remaining alive up to 5 days were chilled according to the protocol of (OIE, 2012). The collected allantoic fluids (AF) were tested by rapid hemagglutination test (HA) for the presence of hemagglutinating activity. Rapid HA Test was performed for 
suspected samples according to Terregino and Capua (2009).

\subsection{Hemagglutination (HA) and Hemagglutination inhibition (HI) tests:}

$\mathrm{HA}$ and $\mathrm{HI}$ tests were carried out according to (OIE, 2012). The harvested AF of each isolated samples was tested against a panel of reference positive sera (GD, Holland) including: Newcastle Disease (ND), Egg Drop Syndrome (EDS) and Avian Influenza (AI) by using HI test.

\subsection{Molecular identification by RT-PCR:}

The tested samples were genetically identified by RT-PCR following the same protocol described by (Mase et al., 2002). RNA extraction from the Allantoic Fluids well as standard ND virus as positive control by RNA extraction kit (QI Aamp viral RNA Mini kit, Qiagen, Germany, GmbH, Cat. 52904).

The extracted viral RNA was then amplified by RT-PCR test using (QIAGEN One Step RT-PCR Kit, Cat.210210) and using specific primers for the $\mathrm{F}$ gene of NDV as shown in Table (2). The RT-PCR reaction scheme was one cycle at $50{ }^{\circ} \mathrm{C}$ for $30 \mathrm{~min}$., one cycle at $95{ }^{\circ} \mathrm{C}$ for $30 \mathrm{~min}$., followed by 35 cycles of $\left(30 \mathrm{sec}\right.$. at $94{ }^{\circ} \mathrm{C}, 45 \mathrm{sec}$ at $55^{\circ} \mathrm{C}$, $72^{\circ} \mathrm{C}$ for $1 \mathrm{~min}$. and one cycle at $72{ }^{\circ} \mathrm{C}$ for 10 $\min )$.

\subsection{Sequencing:}

The PCR products were detected and analyzed by $1 \%$ agarose gel electrophoresis (Sambrook et al., 1989) with modifications. The PCR product of NDV (No.1) isolated from Qaliobia Governorate was selected to be purified by QIA quick PCR product extraction kit (Qiagen, Valencia CA) then partially sequenced by the Big Dye terminator V3.1 Cycle sequencing kit (Perkin-Elmer).
Purification of the sequence reaction by Centrisep spin column (ABI, USA) and the coding sequences were generated using Applied Biosystems 3130 genetic analyzer (ABI, USA). Creating the phylogenetic tree was done by the Meg Align module of Laser gene DNA Star and Mega 5 Version 6.5 software for multiple alignment.

The sequence analysis was compared with the sequences posted in Gene bank of other Egyptian and Standard Vaccinal NDV strains by the aid of BLAST search program.

\subsection{Pathotyping of locally isolated NDV:}

In vivo pathogenicity test:

The NDV isolate pathotyped using the intracerebral pathogenicity index (ICPI)in 10 one day old chick according to the scoring system reported by (Anon, 1971).

\subsection{Virus propagation and titration} acc.to (OIE,2017):

Virus propagation was performed for four serial passages, the AF containing the infectious virus was diluted 10-fold serial dilution using PBS pH7.2 up to $10^{-4}$ for virus propagation and $10^{-15}$ for virus titration. SPFECE, 9-10 day old, were inoculated in the allantoic cavity for viral propagation as reported by (Allan et al., 1973) and AF from HA positive eggs was pooled and aliquoted at $\left(-70 C^{0}\right)$.

Titration of ND virus was done by inoculation of the virus dilution in to allantoic cavity of 9 days old, SPF-ECE after 5 days incubation period, the AF of dead and live eggs were examined for HA activity using HA test and the virus titer calculated by Reed and Muench (1938) as 50\% egg infectious dose $\left(\mathrm{EID}_{50}\right)$. 


\section{Results}

\subsection{Virus isolation, identification and characterization of NDV:}

The inoculated ECE were examined for hemagglutinating activity by HA. It was found that 4 chicken flocks out from a total of 31flocks were positive for HA test.

By $\mathrm{HI}$ test it was found that the 4 isolated samples were AI and EDS negative and positive with NDV antisera.

Also, the results of RT-PCR test for presence of $\mathrm{F}$ gene confirmed that the 4 isolates were NDV positive where they yielded a strong positive reaction as shown in (Figs.1\&2).

\subsection{The genetic analysis of the isolated} $N D V$ :

The Qaliobia governorate chicken isolate No.(1), was selected from the 4 samples for sequencing, it was shown from the phylogenetic tree (Figure 3) and (Table 3) of identity that the isolated virus sample was generally characterized as NDV and named as NDV-ch-EG-CLEVB-F604-2016 (NDVF604) with accession number MHO78055.

Also it felling to the genotype VIId reference ND strains that was isolated at 2011, 2012 from China and Egypt respectively with about 90.3 - 91.9 identity \%, meanwhile the similarity between the local isolate ( NDV-chEG-CLEVB-F604-2016 ) and the classical standard ND virus strain ( NDV-ch-EG-SR76) that was isolated from Egypt by Sheble and Reda (1976) was $81.5 \%$.

On the other hand , the identity $\%$ of the ND isolate with different standard Vaccinal ND strains ranged from $76.6 \%$ ( for Lasota $\mathrm{NDV} \& \mathrm{VG} / \mathrm{GA}$ ) , $77.4 \%$ ( for HB \& Clone30 ), 75\% ( with Ulster67) and 79.8\% ( for Vectormune ND strain ). While the identity $\%$ between the classical standard strain ( SR/76 )that is related to genotype VI with the same vaccinal strains is $79 \%, 79.8 \%$ $, 79.8 \%, 84.7 \%$ respectively as shown in (Table

3.3 Results of Pathotyping, Virus propagation and titration:

The ICPI value of Qaliobia governorate chicken isolate was 1.51 , so considered to be virulent strain, as shown in (Table 4), While, on the other hand, the HA titer of the this NDV isolate after propagation was $10 \log _{2}$ and by ECE inoculation, $\mathrm{EID}_{50}$ : was $10^{9.7}$ $\mathrm{EID}_{50} / \mathrm{ml}$. 


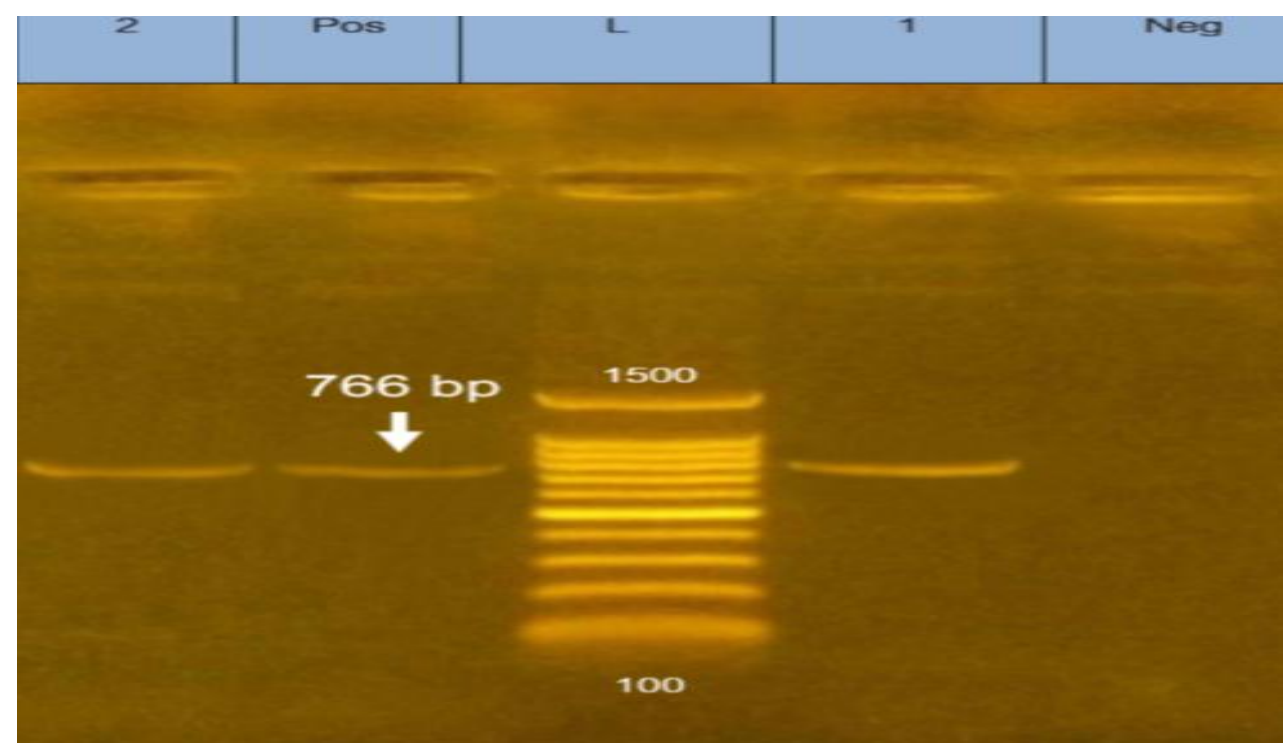

Fig. (1): shows the PCR product of gene of NDV of sample 1,2.

Lane 1: PCR product of $F$ gene sample no. 2.

Lane 2: PCR product of positive control(766bp).

Lane 3: 100bp DNA ladder.

Lane 4: PCR product of $F$ gene sample no.1.

Lane 5: PCR product of negative control.
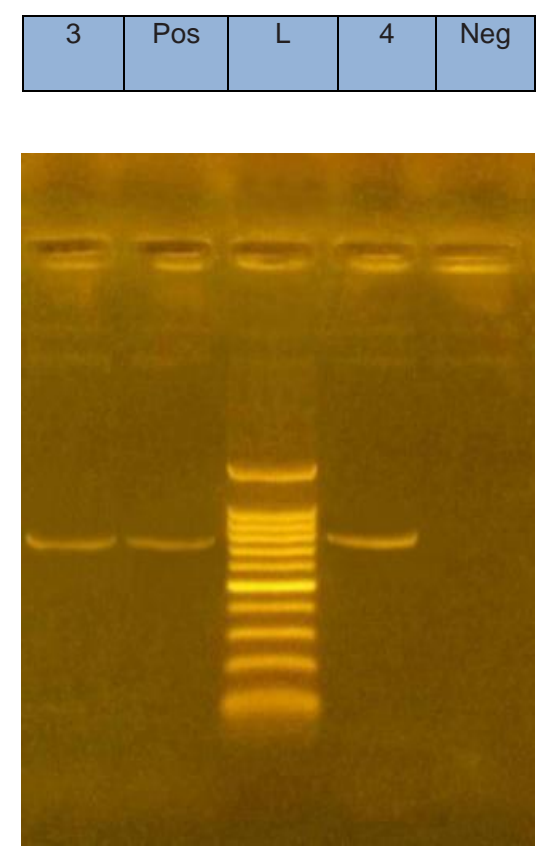

Fig. (2): shows the PCR product off gene of NDV of samples 3,4.

Lane 1: PCR product of $F$ gene sampleno.3.

Lane 2: PCR product of positive control.

Lane 3: 100bp DNA ladder.

Lane 4: PCR product of $F$ gene sample no.4.

Lane 5: PCR product of negative control 




Fig. (3): Phylogenetic tree of the NDV isolate ( $\Delta$ NDV-ch-EG-CLEVB-F604-2016). 
Table (1): Suspected APMV-1 samples from chicken and turkey farms during 2015, 2016 from different provinces in Egypt.

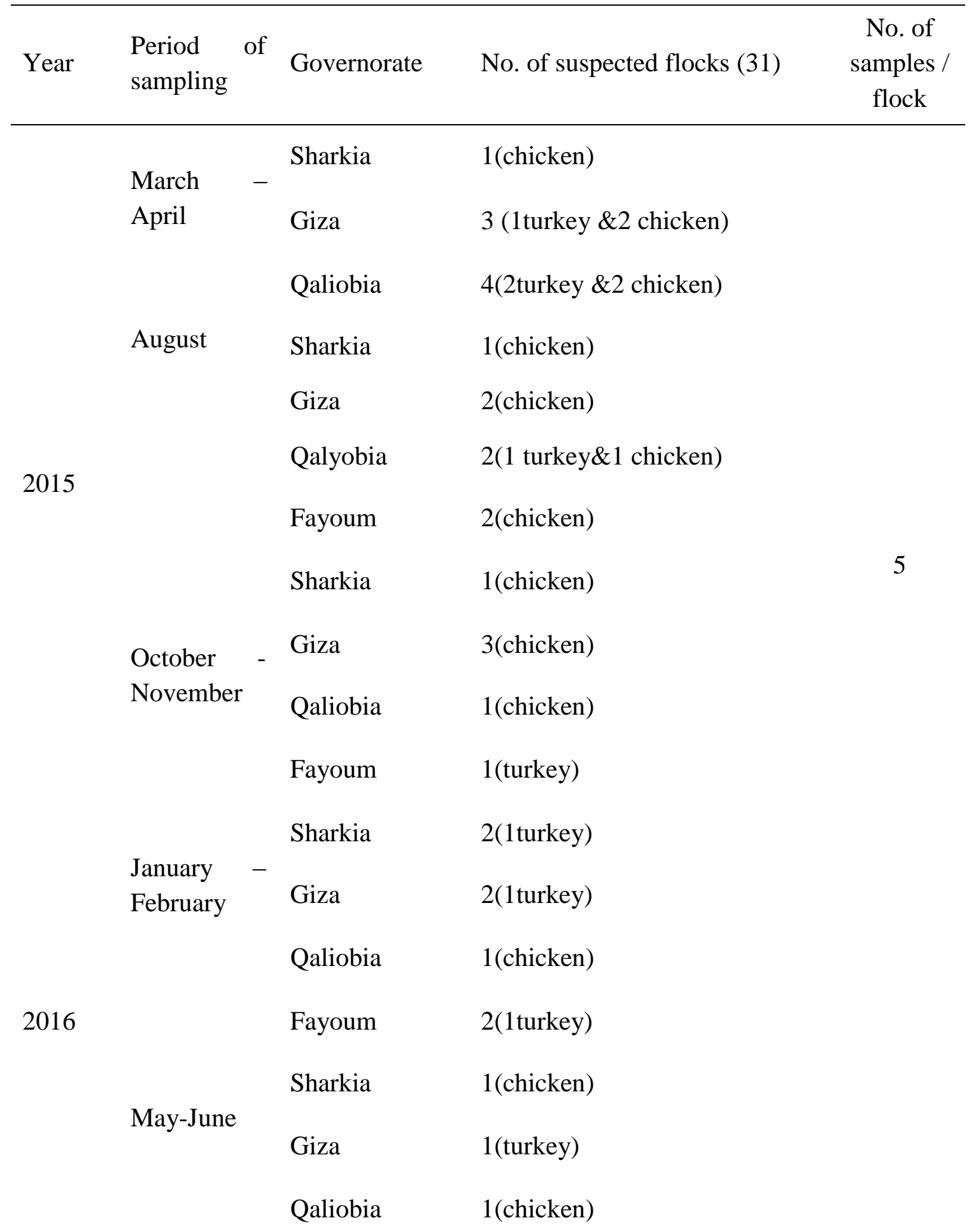


Table (2): Specific primers sequence toward the F gene of NDV.

\begin{tabular}{|c|c|c|c|c|}
\hline $\begin{array}{l}\text { Primers } \\
\text { name }\end{array}$ & Primer Sequences & $\begin{array}{l}\text { Amplified } \\
\text { segment (bp) }\end{array}$ & Ref. & $\begin{array}{l}\text { Supplied } \\
\text { from }\end{array}$ \\
\hline F gene- $\mathrm{R}$ & 5'-TGGAGCCAAACCCGCACCTGCGG-3' & \multirow[b]{2}{*}{766} & Mase & Metabion \\
\hline $\mathrm{F}$ gene- $\mathrm{F}$ & 5'- GGAGGATGTTGGCAGCATT-3' & & $\begin{array}{l}\text { et al., } \\
2002 .\end{array}$ & \\
\hline
\end{tabular}

Table (3): percent of identity between the NDV isolate (NDV-ch-EG-CLEVB-F604-2016), classical local virulent (NDV-ch-EG-SR-76) strain and the other different vaccinal and reference strains.

\begin{tabular}{|c|c|c|}
\hline \multirow[b]{2}{*}{ Different NDV strains } & \multicolumn{2}{|l|}{ Sequence identity $\%$} \\
\hline & $\begin{array}{l}\text { Newly Isolated strain } \\
\text { DV-ch-EG-CLEVB-F604-2016 }\end{array}$ & $\begin{array}{l}\text { Standard strain } \\
\text { NDV-ch-EG-SR-76 }\end{array}$ \\
\hline NDV-LASOTA-II-fusion & $76.6 \%$ & $79 \%$ \\
\hline NDV-isolate Hitchner fusion genes & $77.4 \%$ & $79.8 \%$ \\
\hline NDV-clone 30 & $77.4 \%$ & $79.8 \%$ \\
\hline NDV-VG/GA-(avenu) & $76.6 \%$ & $79.8 \%$ \\
\hline Vectormune NDV strain & $79.8 \%$ & $84.7 \%$ \\
\hline NDV-CHICKEN/N.Ireland/Ulster/67 & $75 \%$ & $79.8 \%$ \\
\hline APMV-CH-China-SDWF07-011-V-V11 & $91.9 \%$ & $88.7 \%$ \\
\hline NDV-B110-RLQP-CH-EG-012 & $90.3 \%$ & $87.1 \%$ \\
\hline NDV-ch vercu138/Egypt/2012 & $91.2 \%$ & $87.5 \%$ \\
\hline NDV-ch-EG-SR-76 & $81.5 \%$ & ID \\
\hline NDV-ch-EG-CLEVB-F604-2016 & ID & $81.5 \%$ \\
\hline
\end{tabular}

Table (4): ICPI result of NDV isolate (NDV-ch-EG-CLEVB-F604-2016).

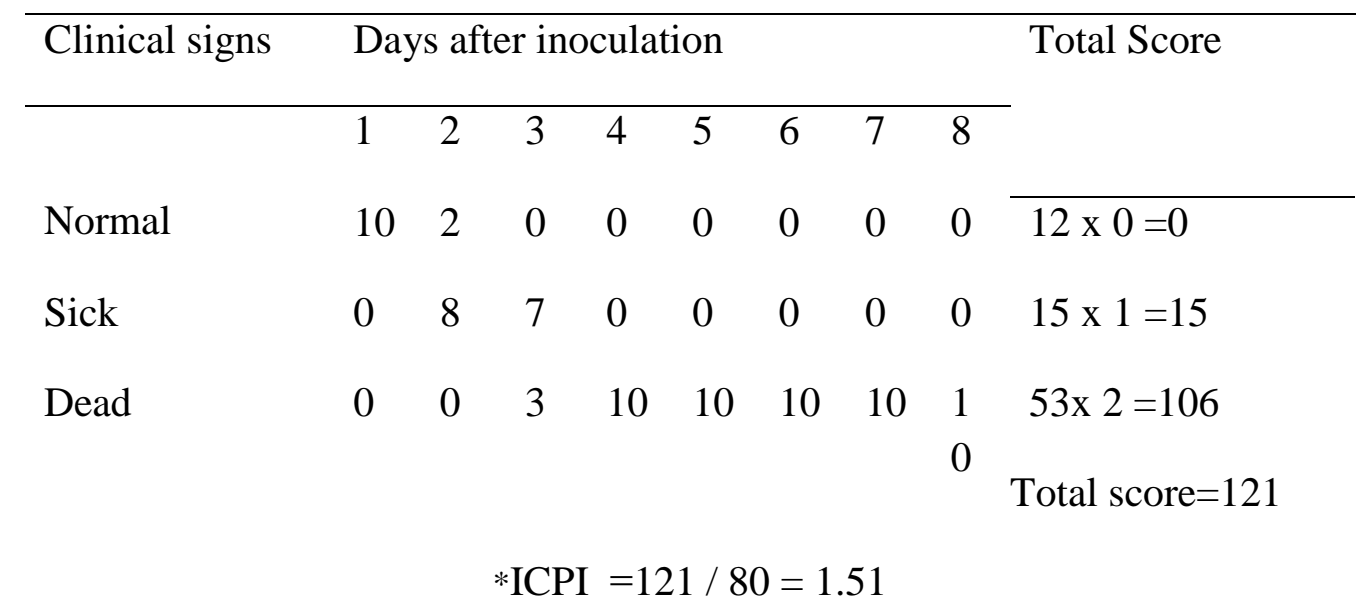

* ICPI: Intra Cerebral Pathogenicity Index. 


\section{Discussion:}

Respiratory infections are of paramount importance in poultry industry due to causing high mortality. The etiology of respiratory disease is complex, often involving more than one pathogen at the same time, as avian influenza virus (AIV) and Newcastle disease virus (NDV). These pathogens are of major influence because they can cause disease independently, in association with each other, or in association with bacterial or viral agents (Yashpal et al., 2004).

ND outbreaks occur frequently in Egypt and the source of the virulent NDV in these outbreaks are not known (Mohamed et al., 2009).

Virus isolation (VI) techniques is considered the reference standard for the diagnosis of animal viruses as well as NDV in the collected samples (OIE, 2012).

It is necessary to confirm the presence of virus in an index case and to perform further characterization of the virus, where (ECE) is the most widely used \& sensitive host system for the isolation \& propagation of poultry adapted NDV (Alexander, 1997).

Additional test as HA assay on the fluids from eggs inoculated with tested samples was applied to confirm the presence of ND virus (Chaka et al., 2013). Four chicken flocks from 31 infected flocks were positive for HA test.

The positive HA samples were then tested by $\mathrm{HI}$ assay to differentiate ND virus from other hemagglutinating virus like AI and EDS (Chaka et al., 2013). It was found that all the positive HA samples were negative for AI and EDS antisera. Once avian AI \& adenoviruses had been ruled out, the presence of ND virus was confirmed by standard specific ND antisera. This agreed with (Alexander, 2000) who said that $\mathrm{HI}$ is the method of choice, most convenient, rapid \& economical serological method for detection $\&$ evaluation of immunity of chickens to ND viruses.

Also, RT-PCR technique using specific set of primers against $\mathrm{F}$ gene of ND was successful in analysing the isolated samples and confirming the presence of NDV (photo1,2). This was in parallel to data from (Tang el al., 2012) who said that the application of molecular methods for the detection of Nucleic Acid has become an important, high speed and low-cost tool for detection of ND virus.

To characterize the molecular epidemiology of recent outbreaks in Egypt, characterization of the isolated NDV strain was conducted by sequencing. Partial F-gene sequence of NDV isolate was compared with reference strains representing the isolated and vaccinal strains.

Qaliobia governorate broiler chicken isolate was selected for $\mathrm{F}$ gene partial sequencing; phylogenetic analysis suggests that the new isolated ND strain at 2016 in Egypt demonstrate that it is nearly identical to the other strains circulating in Egypt since 2012 (Table 3). Comparison of nucleotide sequences of the isolated ND strain included in this study with other published local isolates revealed that it has $90.3-91.2 \%$ homology with strains isolated at 2012, 81.5\% with standard NDV (SR/76) strain. While the ND isolate of 2016 characterized in this study have lower Identity with the different vaccinal strains (76.6\% for lasota, $77.4 \%$ for $\mathrm{HB}_{1}, 75 \%$ for ulster \& $79.8 \%$ for vectormune ND strains), also the similarity \% of VVNDV of genotype 
VI (SR/76) with the same vaccinal strains is $79 \%, 79.8 \%, 79.8 \%, 84.7 \%$ respectively as shown in (Table 3).

This newly isolated Egyptian ND strain was tested for determination of their virulence for chicken using ICPI test, the ICPI was 1.51 indicating that it was classified as virulent virus for chicken (Table 4). This was agreed with (OIE, 2017) that mentioned that any NDV yielding a value reaching 0.7 or greater in an ICPI test is considered to be virulent virus, also, it was found that, the ND isolate had a titre of $10^{9.7} \mathrm{EID}_{50} / \mathrm{ml}, 10^{10} \log _{2} \mathrm{HA}$ units/ml.

Also, it was found that viruses from genotype VIId were predominantly responsible for ND outbreaks since 2012 in Egypt (Radwan et al., 2013). Most of the newer NDV strains were clustered together with (Occupied Palestine) \& Chinese strains (Miller et al., 2015). So, the new NDV subgenotype that are spreading among several countries have the potential to develop into panzootic viruses and should be further monitored (Miller et al., 2015).

The factors that allow a virus to become capable of creating a panzootic are unknown. However, some factors such as the movement of live birds without quarantining. Also lack of testing to ensure a disease-free status or the inability to contain and eradicate a disease after an outbreak is identified, are likely to increase the risk of creating a panzootic. Other human factors that may play a role are the lack of efficient veterinary \& diagnostics services or cultural and Socio-economic factors as backyard or lack of economic stimulus to conduct culling and or reporting (Walker et al., 1973).

Also, other Biological factors are likely important as an increased capacity of the virus to replicate in a host without producing clinical sigs of disease or the existence of highly mobile hosts, are considered as they have the potential to create natural reservoirs in wild birds (Takakuwa et al.,1998).

The epidemiological information available shows that new viruses are capable of replacing prevalent strains in vulnerable countries. The phylogenetic differences document shows these sub-genotypes differ from previously described sub-genotypes (Diel et al., 2012). The countries that are not geographically linked and however, VNDV infections of poultry in these countries with strains that are nearly identical (98.3-98.9\%) indicate a common origin. Viruses from the new sub-genotype that appear in Egypt since year 2012 may be rapidly replacing VNDV isolates from predominant sub-genotype as is happening with (Occupied Palestine) isolates of sub-genotype VIIb and VIId, Chinese isolates of genotype VIId and Pakistani isolates of genotype XIIIa.

The VNDV isolates that are causing a new panzootic in Asia don't appear to have originated from the prevalent poultry vNDV strains from genotype VII, but rather from older strains that were isolated in the 1980's from wild birds. While genotype VII is the most diverse among all of the NDV genotypes, worldwide with its diversity leading to classification first in to ten subgenotypes and then re-classification in to five sub-genotypes (VIIb, VIId, VIIe, VIIf \& VIIg) (Diel et al., 2012).

Egypt considered one of the largest concentrations of backyard poultry \& its poultry production system have characteristics that may help in the emergence of VNDV isolates as well as other viral diseases diverse enough to be a new sub-genotype. Also, the abundance of live bird's markets selling birds 
of multiple species \& ages play an important role in the maintained and evolution of VNDV strains. This agreed with (khan, 2009) who explained that despite considerable efforts, the sanitary measures to control AI in Indonesia \& Pakistan have not been sufficient to prevent new NDV outbreaks.

our present work described represent that recent ND outbreaks still circulate in the field which emerged in Egypt since 2012 causing losses in the poultry industry.

However, the emergence of AI has facilitated increased surveillance \& improved bio-security, all have not been enough to

Also, spillover of vNDV isolates from wild birds to poultry should be further studied due to raising the possibility of cutting distances over poultry facilities between countries playing a role in the spread of the disease which agreed with (Haddas et al., 2013) who mentioned that various species of migratory birds in (Occupied Palestine) that pass over the country on their migratory seasonal journeys may shed VNDV in their faces without showing clinical signs. The problem

\section{References}

AIdous, E.W., Mynn, J.K., Banks, J. and Alexander, D.J. (2003). A molecular epidemiological study of APMV-1 (NDV) isolates by phylogenetic analysis of a partial nucleotide sequence of the fusion protein gene. Avian Pathology, 32(3), p.: 239-257.

Alexander, D.J. (1988). Historical aspects, p. 1-10. In: D. J. Alexander (ed.), Newcastle disease. Kluwer Academic Publishers, Boston, MA.

Alexander, D.J. (1997); Newcastle disease and avian paramyxovirus infections in: Disease of poultry, Calnek, B. W.; prevent the spread of VNDV (Wasilenko et al., 2012).

The use of different types of live and inactivated vaccines for NDV that are able to induce sufficient $\mathrm{Ab}$ levels may not be sufficient to control ND outbreaks under current production conditions in Egypt. This is in parallel with (Miller et al., 2015) who said that in (Occupied Palestine) intensive vaccination $\&$ lower risk production practices were insufficient to prevent the new panzootic, thus suggesting the existence of additional epidemiological factors that favour the spread of the virus.

in (Occupied Palestine) may be replicated in the outer nearby countries middle-east as Egypt that had not yet conducted large epidemiological studies an vNDV (Anonymous, 2011). Conclusively, the circulation of VNDV isolates from new subgenotypes in different regions as the world indicates that there are very few geographic boundaries for VNDV in existence within its susceptible

host.

Barnes, H. J.; Beard, C. W., McDougald, L. R. and Saif Y.M., Eds.), 10th edition, Iowa State University Press Ames, USA. P: 541569.

Alexander, D.J. (2000); Newcastle disease and other avian paramyxoviruses. Rev. Sci. Tech. 19, p.: 443- 462.

Allan, W.H., Lancaster, J.E. and Toth, B. (1973). The production and use of Newcastle disease vaccine, Rome, Italy.53. p.: 1115

Anon, (1971). Methods of examining poultry biologics and for identifying and quantifying avian pathogen . National 
Academy of sciences.

Washington D.C., p.: 270-279

Anonymous, (2011). World livestock Disease Atlas. A quantitative analysis of global animal health Data (2006 - 2009), World bank and TAFS Forum, The World Bank for Reconstruction and Development, The World Bank, Washington, DC and TAFS forum, Bern.

Chaka, H., Goutard, F., Gil, P., Abolnik, C., Almeida, R., Bisschop, S.P.R., Thompson, P.N. (2013). Serological and molecular investigation of Newcastle disease in household chicken flocks and associated markets in Eastern Shewa zone, Ethiopia. Trop. Anim. Health Prod. 45:705-714.

Diel, D.G., Da Silva, L.H., Liu, H., Wang, Z., Miller, P.J., Afonso, C.L., (2012). Genetic diversity of avian paramyxovirus type 1: proposal for a unified nomenclature and classification system of Newcastle disease virus genotypes. Infect. Genet. Evol. 12, p.:1770-1779.

Haddas, R., Meir, R., Perk, S., Horowitz, I., Lapin, E., Rosen bluth, E., Lublin, A. (2013). Newcastle disease virus in little Owls (Athene noctua) and African penguins (Spheniscus demersus) in an Israeli Zoo. Trans boundary Emerg. Dis.

Kattenbelt, J.A., Stevens, M.P., Gould, A.R. (2006). Sequence variation inthe Newcastle disease virus genome. Virus Research, 116(1-2),168-184.

Khan,T.A. (2009). Molecular characterization of velogenic viscerotropic Newcastle disease virus (VVNDV) in chickens from recent outbreak in Pakistan, Physiology. University of Karachi, Karachi.

Leslie, J., (2000). Newcastle disease: outbreak losses and control policy costs. Vet. Rec. (146), P. 603-606.

Lomniczi, B., Wehmann, E., Herczeg, J., Ballagi-Pordany, A., Kaleta, E. F., Werner, O., Meulemans, G., Jorgensen, P. H., Mante, A. P., Gielkens, A. L. J., Capua, I. and Damoser, J. (1998). Newcastle disease outbreaks in recent years in Western Europe were caused by an old (VI) and a novel genotype (VII). Arch. of Virol., 143: 49-64.

Mase, M., Imai, K., Sanada, Y., Sanada, N., Yuasa, N., Imada, T., Tsukamoto, K. and Yamaguchi, S.., (2002). Phylogenetic Analysis of Newcastle Disease Virus Genotypes Isolated in Japan. J. OF Clin. Microb., (40), 10, p. : $3826-3830$.

Miller, P.J., King, D.J., Afonso, C.L., Suarez, D.L. (2007). Antigenic differences among Newcastle disease virus strains of different genotypes used in vaccine formulation affect viral shedding after a virulent challenge. Vaccine, 25, 7238-7246.

Miller, P. J.; Decanini, E. L. and Afonso, C. L., (2010). Newcastle disease: evolution of genotypes and the related diagnostic challenges. Infection, Genetics and Evolution, 10: 26-35.

Miller, P.J., Haddas, R., Simanov, L., Lublin, A., Shafqat Fatima Rehmani, Abdul 
Wajid, Tasra Bibi, Taseer Ahmad Khan, Tahir Yaqub, Surachmi Setiyaningsih, Claudio L. Afonso, (2015) Infection, Genetics and Evolution 29, 216-229. Identification of new sub-genotypes of virulent Newcastle disease virus with potential panzootic features.

Mohamed, M.H., Kumar, S., Paldurai, A., Megahed M.M., Ghanem, I.A., Lebdah, M.A., Samal, S.K., (2009). Complete genome sequence of a virulent Newcastle disease virus isolated from an outbreak in chickens in Egypt. Vir. Gen., 39, p. :234-237.

OIE, (2012). Newcastle disease. Chapter 2.3.14. OlE manual of standards for diagnostic tests and vaccines. Version adopted by the World Assembly of Delegates of the OIE in May 2012.

OIE, (2017). Terrestrial Animal Health Code. Infection with Newcastle Disease Virus. Chapter 10 .9. Art. 10.9.1. p.:1-10.

Radwan, M.M., Darwish, S.F., El-Sabagh, I.M., El-Sanousi, A.A. Shalaby, M.A. (2013). Isolation and molecular characterization of Newcastle disease virus genotypes II and VIId in Egypt between 2011 and 2012.Vir. Gen., 47, p.: 311-316.

Reed, L. J. and Muench, H., (1938). A simple method for estimating fifty percent endpoints. Am. J. Hyg. ,27, p.: 493497.

Sambrook, J.; Fritscgh, E.F.; and Mentiates, (1989). Molecular coloning. A laboratory manual. Vol 1, Cold spring Harbor Laboratory press, New York.

Sheble, A. and Reda, I.M., (1976). Cited by Khafagy, A.K. (1977). Thesis M.V.Sc. Fac. Vet. Med., Cairo Univ.
Swayne, E. (2013). Newcastle disease in Diseases of Poultry: Glisson, J. R., McDougald, L. R., Nolan L.K., Suarez, D.L. and Nair, V. L. WileyBlackwell Publishing, Ames, Iowa, USA, 13th Ed.

Takakuwa, H., Ito, T., Takada, A., Okazaki, K., Kida, H., (1998). Potentially virulent Newcastle viruses are maintained in migratory waterfowl populations. Jpn. J. Vet. Res., 45, p. :207-215.

Tang, Q., wanga, J.,Bao, J., Sun, H., Sun, Y., Liu, J., Pu, J. (2012). A multiplex RT-PCR assay for detection and differentiation of avian $\mathrm{H} 3, \mathrm{H} 5$, and H9 subtype influenza viruses and Newcastle disease viruses. J. Virol. Methods.181, p. :164-169.

Terregino, C. and Capua, I. (2009) Conventional diagnosis of Newcastle disease virus infection. In: Avian influenza and Newcastle disease, a field and laboratory manual (Eds.), Springer Milan, Milan, Italy, p.: 123125.

Walker, J.W., Heron, B.R., Mixson, M.A., (1973). Exotic Newcastle disease eradication program in the united states. Avian Dis. 17, p.: 486-503.

Wasilenko, J.L., Pantin-Jackwood, M., Khan, T.A., Ahmed, A., Rehmani, S.F., Lone, N.A., Swayne, D.E., Spackman, E., (2012). Characterization of H5N1 Highly pathogenic avian influenza viruses isolated from poultry in Pakistan 20062008. Vir. Gen., 44, p.: 247-252.

Yashpal, S. M., Devi, P.P. and Sagar. M.G. (2004). Detection of three avian Respiratory viruses by single tube Times New Roman (Headings Times New Roman (Headings CS)CS)multiplex reverse transcription-polymerase chain reaction assay. J. Vet. Diag. Invest., 16, p.: 244248. 

Monir et al., 18, BVMJ-34(2):265-277 